\title{
Students Learning Result of Social Science Subject between Full Day School and not Full Day School Program
}

\author{
Indra NurFajrah Bolonan, Haris Mahmud \\ Universitas Negeri Gorontalo, Gorontalo, Indonesia \\ e-mail: $\underline{\text { harismahmud2017@gmail.com }}$
}

\begin{abstract}
The research purpose was to know different of student learning result of social science subjects in the full day school program and not the full day school program. The sample in this research was 30 students taken from the full day school program and 24 students taken from not the full day school program. The research method used comparative methods by using one shot case study. Data was analyzed by using the normality test, homogeneity test and t-test. It was conducted at primary school of SDN 11 Limboto for full day school program and SDN 10 Kabila for not full day school program. The result shown that students learning result of social science subject in the full day school program were higher then not the full day school program. Hypotesis show that $\mathrm{t}$-count $>\mathrm{t}$-table $(2.511>1,674)$ with $\alpha=0.5, \mathrm{df}=\mathrm{n} 1+\mathrm{n} 2-2$, seen from the variance value of $\mathrm{X}_{1}=38.52$ with average 80.40 , and varian value of $\mathrm{X}_{2}=30.49$ with average $=76.33$. So, $\mathrm{H}_{0}$ refused and Ha accepted. And it can be concluded that have different students learning result of social science between full day school and not the full day school program.
\end{abstract}

Keywords: $\quad$ Students Learning Result, Social Science, Full Day School 


\section{INTRODUCTION}

Full day school is a school-run program, where students engage in classroom learning and other school programs, as well as programs that reflects their daily life. In this program, students may complete their homework under teachers' supervision in the classroom. Yet, this does not mean the program discourages students from not playing and continuously learn in the classroom. Instead, the program embraces methods and learning media which include classrooms and surrounding environment that teachers can use to deal with students' boredom issue. In addition, the program helps school to manage effective school hours because it also entails informal activities.

The main reason for optimalising school hours is believed to be related to parents' demands. Parents are concerned over their children socialization, learning progress, and family interaction itself. They also expect to be able to provide their children with facilities for developing their potential learning improvement.

Many assume that todays' learning phenomenon shows unsatisfying results. On the basis of the results of observation and interviews on 8 March 2017 at the research site, the researcher of the present study found that $75 \%$ of the students in the higher level at Sekolah Dasar Negeri 10 or SDN 10 (henceforth refers to the State Primary School 10 ), a school without the full-day program, has met KKM criteria, while $25 \%$ failed. The research focused on students' Learning Result on Social Science subject at full day and regular schools. The findings indicate that such KKM fulfilment was affected by the limited school hours which allows students to choose any activity that suits their ability, as well as friends to play with.

Findings from other school with the full day program revealed that students in higher level at the State Primary School 11 in Limboto were more prepared in learning than the students from half-day schools or regular schools. This impacts on students' Learning Result on Social Science subject. It was also found that many students were bored and not interested to attend lessons because of the relatively long school hours. Therefore, teachers need to ensure the enjoyable aspects of their teaching practices and be committed to induce the values of independent learning, integrity and being skillful. The long school hours cause students to become individualistic, introvert, and to demonstrate low level of cognitive aspects due to their limited interactive spaces.
In order to optimalise students' learning outcome in Social Science subject, schools may need to administer a full day program, a program which can address parents and society's concerns over students' academic and attitude-related achievement. To this end, the present study investigates the differences of the Learning Result on Social Science subject of students in full day and regular schools.

Such potential differences in students' Learning Result have encouraged the researcher of the present study to investigate an undergraduate thesis entitled The differences of students' Learning Result in full day and regular schools on Social Science subject at the State Primary Schools in Gorontalo.

The goal in teaching and learning is essentially a result describing that students have completed a series of learning process, which generally includes some aspects that they are expected to gain, such as knowledge, skills, and novel behavior. Sunal in Santoso (2016:5) asserts that students Learning Result describe skills that they acquire after learning which are assessed using an evaluation technique to evaluate their knowledge, skills, and behavior development related to a particular subject.

Students Learning Result play an important role in education because it is the goal for the learning process itself. The process demonstrates changes in students behavior in some aspects, such asknowledge, values, skills, and teaching quality, which is essential in determining Learning Result (Suprijono, 2012:6).

Changes in students' behavior, which is relatively static, may be reflected in any students activity following classroom learning. In other words, teacher can evaluate the level of students' mastery of what they learn by using assessment. Such assessment, according to Rasyid and Mansyur (2009:7), is useful for assessing students' Learning Result which include a range of aspects they learn. At the school contexts, students' success in learning depends on to what extent they successfully achieve the learning objectives prescribed by their teachers (Abdurahman, 1999: 18).

There are several factors that determine students' success in learning. Sutikno (2008: 59-63) claims that"bahwa yang mempengaruhi pencapaian hasil belajar yaitu dari dalam diri orang yang belajar dan ada pula dari luar dirinya"(what influences Learning Result arises from within learners and their surroundings).

It can be concluded that, based on the definition of learning oucomes mentioned earlier, 
Learning Result is a result from learning and teaching interactions, skills that students acquired during a learning process or activity, which can be knowledge and final results of the decision making process pertaining to the various level of students' scores. From teachers' perspectives, teaching activity ends with evaluating Learning Result, whereas from students', Learning Result is the end of and the increases in students' skill level.

The term full day school is derived from the English language (Echols, 2008). It means all day learning activities which include religious worships and two break time sessions. According two Baharuddin (2014:221), full day school focuses on how schools manage subject timetables, the level of difficulties of school subjects, and intensive learning of particular subjects.

On the basis of its implementation and functions, full day schools allocates certain amount of time for informal teaching sessions, which is fun and enjoyable for students. To this end, teachers are encouraged to be creative and innovative in teaching. Annisa (2014:26) believes that "bahwa belajar yang efektif bagi anak itu hanya tiga sampai empat jam sehari dalam suasana formal dan tujuh sampai delapan jam sehari dalam suasana informal" (students need approximately 3-4 hours of formal instructions and 7-8 hours of informal instructions during the day for an effective learning to take place).

In full day schools,improvement in students competence can be monitored by focusing on their situation during learning and playing sessions. Baharuddin (2014:222) states that "bahwa pada pembelajaran full day school tidak hanya dilakukan di dalam kelas, namun siswa diberi kebebasan untuk memilih tempat belajar sehingga siswa tidak terbebani dan merasa bosan ketika berada disekolah" (full day school students are given the opportunities to choose where to learn so that they do not feel bored and forced during school hours).

Hasan in Septiana (2012:9) suggests some purposes of implementing full day school programs in several educational institutions. These include:

1. Schools are able to control students' activity after school hours, as well as to ensure the quality of their graduates (based on the results of the students' final examination)

2. Parents in big cities are getting busier to cope with their needs, and they have limited time to observe their children's activities. As a result, many of their children commit crime, feel demotivated in learning, and are addicted to games. Full day school help parents to address these problems.

3. Full day schools encourage students to be more productive in learning by adding school hours, which is not applicable in regular schools. The students are educated, managed, and facilitated by schools through a range of programs, such as performing Friday prayer where shools teach students the values of worships. By attending this programs, students can be motivated to perform the Friday prayer by themselves. Other programs include learning foreign languages and operating computer applications.

Full day school programsare useful for managing school hours where students are motivated in learning as well as teaching them various positive values. This helps students to improve the quality of their learning.

\section{RESEARCH METHOD}

The present study was conducted at two different schools. The first school was the State Primary School 11 Limboto, located in the District of Gorontalo. The researcher assumed that this school was implementing the full day school programs. The second school was the State Primary School 10 Kabila, located in the District of Bone Bolango, which was a regular school.

In order to examine and compare the differences in the students' Learning Result on Social Science subjects of students from the two schools, the study used a comparison method. This method is classified as statistical quantitative.

Participants were selected using a purposive sampling method. In the study, one group of participants received a treatment and was observed. The treatment was given to both the first and second school. It was classiefied as pre-experimental designsin the form of one-shot case study.

Data collection began with determining which schools and classes to choose for collecting students' mid-term test results. This was done to identify the initial condition of the differences of Learning Result on Social Science Year 4 of students in the State Primary School 11 Limboto and the State Primary School 10 Kabila.

\section{FINDING AND DISCUSSION}

\subsection{Description of the mid-term test results from Full Day Schools}


Data about full day school students' Learning Result were collected from the mid-term test results on Social Science subject in Semester 2 during the $2016 / 2017$ academic year. To analyse the data, the study used a statistical analysis technique. The results of the analysis are in tables 1 and 2 .

Table 1. Description of Learning Result in full day school programs

\begin{tabular}{|c|c|}
\hline Sum of students (N) & 30 \\
\hline Maximum Score & 93 \\
\hline Minimum Score & 69 \\
\hline Range & 24 \\
\hline$(\mathrm{K})$ & 5 \\
\hline$(\mathrm{P})$ & 5 \\
\hline
\end{tabular}

Table 2. Distribution of data frequency of pre-test results from the experiment classes

\begin{tabular}{|c|c|c|c|c|c|c|}
\hline No. & $\begin{array}{c}\text { Kelas } \\
\text { Interval }\end{array}$ & $\mathbf{f}_{\mathrm{i}}$ & $\mathbf{f}_{\text {kum }}$ & $\begin{array}{c}f_{\text {frelatif }} \\
(\%)\end{array}$ & $\mathbf{X}_{\mathbf{i}}$ & $F_{\mathrm{i}} \cdot \mathbf{X}_{\mathrm{i}}$ \\
\hline 1. & $69-73$ & 5 & 5 & 16,67 & 71 & 355 \\
\hline 2. & 74-78 & 6 & 11 & 20,00 & 76 & 456 \\
\hline 3. & $79-83$ & 10 & 21 & 33,33 & 81 & 810 \\
\hline 4. & $84-88$ & 5 & 26 & 16,67 & 86 & 430 \\
\hline 5. & $89-93$ & 4 & 30 & 13,33 & 91 & 364 \\
\hline \multicolumn{2}{|r|}{$\bar{\Sigma}$} & 30 & & 100 & & 2415 \\
\hline
\end{tabular}

\subsection{Description of the Mid-term examination results from the regular school}

Data about Learning Result of the regular school students were collected from the scores of the Social Science subject mid-term test in Semester 2 during the 2016/2017 academic year in the State Primary School 10 Kabila. The data, which were analysed on the basis of statistical analysis (see Attachment 4), were available in Attachment 2 of this present study. The result of the anaylsis is as follows.

Table 3. Description learning outcome data from regular shool

\begin{tabular}{|c|c|}
\hline Sum of students (N) & 24 \\
\hline Maximum Score & 87 \\
\hline Minimum Score & 68 \\
\hline Range & 19 \\
\hline$(\mathrm{K})$ & 5 \\
\hline$(\mathrm{P})$ & 4 \\
\hline
\end{tabular}

The table above shows that the highest score for full day school students' learning outcome is 87 and the lowest is 68 , the value range is 190 with 5 classes in numbers and 4 classes in length. Distribution of frequency of data in table 4.

Table 4. Distribution of frequency of data about

Learning Result from control class

\begin{tabular}{|c|c|c|c|c|c|c|}
\hline No. & $\begin{array}{c}\text { Class } \\
\text { Interval }\end{array}$ & $\mathbf{f}_{\mathbf{i}}$ & $\mathbf{f}_{\text {kum }}$ & $\begin{array}{c}\mathbf{f}_{\text {relative }} \\
(\mathbf{\%})\end{array}$ & $\mathbf{X}_{\mathbf{i}}$ & $\mathbf{F}_{\mathbf{i}} \cdot \mathbf{X}_{\mathbf{i}}$ \\
\hline 1. & $68-71$ & 6 & 6 & 25,00 & 70,5 & 423.0 \\
\hline 2. & $72-75$ & 7 & 13 & 29,17 & 74,5 & 521.5 \\
\hline 3. & $76-79$ & 3 & 16 & 12,50 & 78,5 & 235.5 \\
\hline 4. & $80-83$ & 5 & 21 & 20,83 & 82,5 & 412.5 \\
\hline 5. & $84-87$ & 3 & 24 & 12,50 & 86,5 & 259.5 \\
\hline & $\sum$ & 24 & & 100 & & 1852 \\
\hline
\end{tabular}

\subsection{Analysis requirement test}

The findings suggests that the data was analysed using a hypothesis test. Prio to this test, however, independent T-test which was part of parametric statistic, was applied. The T-tes requiresa nomal data distribution. To do this, the study used Liliefors test.

\section{Normality test}

The hypotheses were:

$\mathrm{H}_{\mathrm{o}}$ : Data is normally distributed

$\mathrm{H}_{1}$ : Data is not normally distributed

The test criteria was to accept $\mathrm{H}_{\mathrm{o}}$ if Lo $\leq \mathrm{L}_{\text {table, }}$, and reject $\mathrm{H}_{\mathrm{o}}$ when $\alpha=5 \%$. The table below displays the result of data normality test of full day school students.

Table 5. Normality test results of full day school students mid-term test

\begin{tabular}{|c|c|c|c|}
\hline Varible & $\mathrm{L}_{\text {cal }}\left(\mathrm{L}_{\mathrm{o}}\right)$ & $\mathrm{L}_{\text {tabel }}$ & Sig. \\
\hline FDS & 0,0948 & 0.161 & $5 \%$ \\
\hline
\end{tabular}

The table above shows that the results contain $\mathrm{L}_{\text {calculate }}=0,0948<\mathrm{L}_{\text {table }}=0,161$. Because the data shows $\mathrm{L}_{\text {calculate }}<\mathrm{L}_{\text {table, }}$ it can be concluded that the data were collected from a normal distributed population.

Table 6. Normality test results of regular school students mid-term test 


\begin{tabular}{|c|c|c|c|}
\hline Varible & $\mathrm{L}_{\text {Cal }}\left(\mathrm{L}_{\mathrm{o}}\right)$ & $\mathrm{L}_{\text {tabel }}$ & Sig. \\
\hline Non FDS & $=0,1371$ & 0,1764 & $5 \%$ \\
\hline
\end{tabular}

The data shows that $\mathrm{L}_{\text {calculate }}=0,1371<\mathrm{L}_{\text {table }}=$ 0,1764 . Because the data shows that $\mathrm{L}_{\text {calculate }}<\mathrm{L}$ table, it can be concluded that the data were collected from a normal distributed population.

\section{Homogeneity of variance test}

Hypotheses:

$\mathrm{H}_{\mathrm{o}}$ : Both classes have the same variance (homogeneous)

$\mathrm{H}_{1}$ : Both classes have different variance (not homogeneous)

The testing criteria is to accept $\mathrm{H}_{\mathrm{o}}$ if $\mathrm{F}_{\text {calculate }}<$ $\mathrm{F}_{\text {table, }}$ and rejected when $\mathrm{H}_{\mathrm{o}}$. shows $\alpha=5 \%$.

Table 7. Additional table calculation

\begin{tabular}{|l|l|l|l|}
\hline \multicolumn{2}{|c|}{ Varians $\left(\mathrm{S}^{2}\right)$} & \multirow{2}{*}{$\mathrm{F}_{\text {hitung }}$} & \multirow{2}{*}{$\mathrm{F}_{\text {tabel }}$} \\
\cline { 1 - 2 }$\left(\mathrm{X}^{1}\right)$ & $\left(\mathrm{X}^{2}\right)$ & & \\
\hline 38.52 & 30.49 & 1,263 & 1,96 \\
\hline
\end{tabular}

Because $\mathrm{F}_{\text {calculate }}=1,263<\mathrm{F}_{\text {table }}=1,96, \mathrm{H}_{\mathrm{o}}$ is accepted, which means both classes have homogeneous variance.

\section{Hypothesis test}

Hypothesis test was conducted by using statistical hypothesis, that is, by calculating the $\mathrm{X}_{1}$ variance value of full day school which is 38,52 , the median is 80,40 and the $\mathrm{X}_{2}$ variance values of the regular school is 30,49 (with 76,33 averaged number of students). If $t_{\text {calculate }}=2,511>t_{\text {table }}=$ 1,674 , then $\mathrm{H}_{0}$ is accepted dan $\mathrm{H}_{1}$ is rejected. The following table describes the summary of the hypothesis test.

Table 8.Summary of hypothesis test

\begin{tabular}{|c|c|c|c|c|c|}
\hline $\begin{array}{c}\text { Variab } \\
\text { el } \\
\text { yang } \\
\mathrm{Uji}\end{array}$ & $\begin{array}{c}\mathrm{R} \\
\text { hitun } \\
\mathrm{g}\end{array}$ & $\begin{array}{c}\mathrm{t} \\
\text { hitung }\end{array}$ & $\mathrm{t}_{\text {tabel }}$ & $\begin{array}{c}\text { Keterang } \\
\text { an }\end{array}$ & $\mathrm{T}$ \\
\hline $\begin{array}{c}\text { Variab } \\
\text { el X } \\
\text { dan } \mathrm{X}_{2}\end{array}$ & $\begin{array}{c}1- \\
0,05\end{array}$ & $\begin{array}{c}2,51 \\
1\end{array}$ & $\begin{array}{c}1,67 \\
4\end{array}$ & $\begin{array}{c}\text { signifika } \\
\mathrm{n}\end{array}$ & $\begin{array}{c}6.3051 \\
21\end{array}$ \\
\hline
\end{tabular}

The value of $t_{\text {hitungis }} 2,511$. This is then compared to $t_{\text {tabel }}$ with $\alpha=0,05$ or at the significance level of $5 \%$ of two tailed test with $d k=n_{1}+n_{2}-$ 2 , which shows the value of $t_{\text {tabelas }} 1,674$. Because $t_{\text {calculate }}=2,511>t_{\text {table }}=1,674, \mathrm{H}_{0}$ is rejected and $\mathrm{Ha}$ is accepted with $1-0,05$ chance.

In other words, the statistical analysis shows that there is a difference in learning outcome results on Social Science subject between full day and regular school students in Year 4 in Gorontalo. Full day school students demonstrate higher level of Learning Result than the regular school students.

\subsection{Discussion}

Full day school programs on the State Primary School 11 Limboto begins from 6am until $2: 30 \mathrm{pm}$. The findings show that the full day school students demonstrate higher level of Learning Result than those of regular schools. The full day school programs allow students to have better preparation for studying and offer them with much opportunities for learning. The programs entails various methods of teaching and utilises learning resources from the surrounding environment. Baharuddin (2014:221) states that school manages subjects timetable, and take into account the level of difficulties of each subject. Additional activity in the program is intensive learning. These are some fundamental aspects of full day school in the State Primary School 11 Limboto. This school prepares a number of supporting elements for students learning succes, such as teaching and learning facilities, learning resources. The school also prepares teachers and students to attend all activities prescribed in the full day school programs.

The findings also reveal that there are no additional subjects related to religiuous teaching, such as the reading of Qur'an (Islamic holy book) and group prayers, in the State Primary School 10 Kabila, a regular school. Anas (2013: 53-54) believes that inclusive schools characteristics can be seen in this full day school programs, such as fun education, enjoyable schools (where students are not forced to do anything), supporting rules that stimulates students' creativity, and relatively easy enrolment (No. school entrance test). These schools allow students to choose any activity they like and to play with their peers. In addition, because the school hours is short, there might be some influences on the students' learning outcome on Social Science subject. In other words, there is a difference in Learning Result between full day and regular school students on Social Science subject in primary schools in Gorontalo.

Full day school programs enable schools and teachers to control students learning activity, and to ensure the quality of the school graduates. Full day 
school students have higher level of readiness in attending Social Science classes because of the long duration of school hours. However, regular school students show low level of Learning Result. This difference is influenced by a number of factors, such as the short school hours and the opportunity to choose any activity in regular school, taking full advantage of school hours so that students can engage in off-school activities that suit their interests, and allowing students to make as many friends as possible outside school setting.

The findings of the study show that variance $\mathrm{X}_{1}$ is 38,52 , the mean is 80,40 , whereas variance $\mathrm{X}_{2}$ is 30,49 , and the mean is 76,33 . Because full day school students have better Learning Result than regular school students, and $t_{\text {calculate }}$ and $t_{\text {table }}$ of the actual level $\alpha=0,05$ or $5 \%$ level of significance of two tailed test with $d k=n_{1}+n_{2}-2$, then it was found that $t_{\text {calculate }}=2,511>t_{\text {table }}=1,674$. Therefore, the $\mathrm{H}_{0}$ is rejected, but the Ha was accepted.

\section{CONCLUSIONS AND SUGGESTION}

\subsection{Conclusion}

There is a difference in the Learning Result between full day and regular school students on Social Science subject in the State Primary School 11 Limboto and the State Primary School 10 Kabila. This is seen from the T-test result that shows the actual level $\alpha=0,05$ or the $5 \%$ level of significance of two tailed test with $d k=n_{1}+n_{2}-2$, then $t_{\text {calculate }}=2,511>t_{\text {table }}=1,674$. Therefore, the $\mathrm{H}_{0}$ is rejected, but the Ha is accepted. The $\mathrm{H}_{\mathrm{a}}$ is that there is a difference in the Learning Result of full day and regular school students on Social Science subject at primary schools in Gorontalo. The Learning Result of the Year 4 full day school students in the State Primary School 11 Limboto is higher that the regular school students in the State Primary School 10 Kabila. This is seen in the statistical test that shows variance $X_{1}$ is 38,52 , the mean is 80,40 , whereas variance $X_{2}$ is 30,49 , and the mean is 76,33 .

Full day school programs do not suggest an additional school hours for particular subject, but the transfer of educational concepts that are available from family settings and the society into the school settings, which can be influential to students learning outcome improvement. There is a difference in the Learning Result between full day and regular school students on Social Science subject in the State Primary School 11 Limboto and the State Primary School 10 Kabila. This is indicated by the highest level of readiness of the full day school students in attending lessons.

\subsection{Suggestions}

1. By implementing full day school programs, students are expected to be well-prepared to attend Social Science classes.

2. By implementing full day school programs, teachers are expected to find ways to success (on the basis of the four competence that they should acquire), to help the 4 Year students improve their Learning Result (particularly in the Social Science subject), and to control students' playing sessions (especially in the regular schools).

3. Schools may need to observe the surrounding environment and offer decent teaching resources, as well as conduct research that focuses on examining the effectiveness of students' Learning Result in Social Science subjects in full day and regular school contexts.

\section{REFERENCES}

[1] Anas, Z. 2013. Sekolah Untuk Kehidupan. Jakarta : Amp Pers \& Pustaka Bina Putera.

[2] Amin, B. "Kampanye Dari Shanti Niketan". Gorontalo Post. Edisi. Januari 2017.

[3] Arikunto, S. 2009. Dasar-Dasar Evaluasi Pendidikan. Jakarta : Bumi Aksara.

[4] Baharuddin. 2014. Pendidikan dan Psikologi Perkembangan. Jogjakarta : Ar-Ruzz Media

[5] Echols, J. 2008. Kamus Inggris Indonesia. Jakarta : Gramedia.

[6] Hamalik, O. 2005. Kurikulum dan Pembelajaran. Bandung: Bumi Aksara.

[7] Hasbullah. 2015. Dasar-Dasar Ilmu Pendidikan. Jakarta : Rajawali Pers.

[8] Agung, I. 2012. Strategi Mengembangkan Organisasi Pembelajar di Sekolah. Jakarta : Bee Media Indonesia.

[9] Jihad A, Haris, A. 2012. Evaluasi Pembelajaran. Yogyakarta : Multi Presindo.

[10] Rahmat A, Rusmin H. 2009. Public Relations for School. Bandung: MQS Publishing.

[11] Rasyid H, Mansur. 2009. Penilaian Hasil Belajar. Bandung : CV Wacana Prima 
[12] Ruhimat T, Wina S, \& Masito. 2013. Kurikulum dan Pembelajaran. Bandung : Raja Grafindo Persada.

[13] Sanjaya, W. 2009. Kurikulum dan Pembelajaran. Bandung : Prenada Media Group.

[14] Santoso, B. 2010. Sekolah Alternatif Mengapa Tidak?. Yogyakarta : Diva Press.

[15] Satmoko. 2016. Buku Pintar Sekolah Alternatif. Jakarta : Pedar Kindi.

[16] Sudijo, A. 2009. Pengantar Statistik Pendidikan. Jakarta : Rajawali Pers.

[17] Sudjana. 1996. Metode Statistika. Bandung : Tarsito.

[18] Sugiyono. 2015. Statistika Untuk Penelitian. Bandung : Alfabeta.

[19] 2015. Metode Penelitian Pendidikan. Bandung: Alfabeta.

[20] Suprijono, A. 2012. Cooperative Learning. Yogyakarta : Pustaka Pelajar.

[21] Susanto, A. 2016. Teori Belajar \& Pembelajaran di Sekolah Dasar. Jakarta : Prenada Media Group.

[22] Sutikno, S. 2008. Landasan Pendidikan. Bandung : Prospect.

[23] Widiyanto, M.A. 2013. Statistika Terapan. Jakarta : Elex Media Komputindo.

[24] Annisa, N.A. 2014. Program Full Day School dalam Pengembangan Kemandirian Siswa Kelas IV di SDIT Insan Utama Bantul. Skripsi. Yokyakarta. Universitas Negeri Yogyakarta. http://smkn1lmj.sch.id/dl/fuldayschool.pdf (online) Diakses Jumat 20 Januari 2017 $(11: 37)$

[25] Jafar, R. 2012. Upaya Meningkatkan Hasil Belajar Siswa Melalui Media Gambar Pada Mata Pelajaran IPS. Skripsi. Universitas Negeri Gorontalo. Gorontalo.

[26] Septiana, S. 2011. Pengelolaan Pembelajaran Program Full Day School di SD Budi Mulia Dua Yogyakarta. http://eprints.uny.ac.id/22371/1/Ragella.pdf (online) Diakses Selasa 28 Februari 2017 (16:20) 